\title{
THE REBIRTH OF THE COMMERCIAL FACTOR
}

Perhaps the commercial factor did not die; perhaps he only seemed to as the spot light shifted to other actors. At one time he had a hand in most of the world's commerce; indigo, hemp, cotton and iron, sugar, shellac, tobacco, pepper, corn, and rum, these things and many others came into the English ports consigned to the factor for sale. ${ }^{1}$ On the outgoing voyage he, or his ubiquitous brother the supercargo, handled the glass beads, ${ }^{2}$ the cutlery, fire water and calico designed to bring civilization, at a price, to the customers contacted by the missionary. It was he also who marketed the antelope, beaver and buffalo skins of which the west was despoiled last century, ${ }^{3}$ and later the mess-pork, lard, flour, cattle, hides and lumber produced by the pioneer. The factor was an important person in his day. Once, indeed, he was widely discussed in legal literature, but that was some time ago.

Considered in retrospect this demise-or seeming demise-of the commercial factor is logical enough. The displacement of the sailing vessel by steam, of the pack train and freighter by the railroad, of the messenger and a leisurely post by telegraph, cable and wireless, of word of mouth selling by national advertising, all have served to bring buyer and seller closer together. The movement increasingly to standardize manufactured products, and in recent years to grade the "raws," though less spectacular, has been fully as significant. So with a stabilized exchange! ${ }^{4}$ But it was probably the onrush of the corporation and industrialism which did more than anything else to squeeze the factor to the wall. Capable of buying direct in large quantities-or of owning outright the sources of supply - and on the selling side of dominating ${ }^{5}$ "wholesaler," "jobber" and "dealer," there was little place left for the

${ }^{1}$ How early the factor appeared is not certain-if important-but at all events he had long been prominent in trading circles by the 17th century. See Malynes, Lex Mercatoria (3d ed. 1681) c. 16.

${ }^{2}$ See Godfrey v. Saunders, 3 Wils. K. B. 94 (1770) involving a shipment of "coral beads" to the East Indies in 1754.

${ }^{3}$ See Argersinger v. MacNaughton, 114 N. Y. 535, 21 N.E. 1022 (1889), a case involving a quantity of antelope skins.

"So also with sound banking - and with the various commodity exchanges.

"Of course this "domination" is not complete, as witness the recent failure of resale price legislation in New York. Doubleday, Doran \& Co. v. R. H. Macy, Inc., 269 N. Y. 272, 199 N. E. 409 (1936). And, equally, the effort to gain control by making the merchant appear both as "factor" or agent and as "buyer" has been disappointing. Frick Co. Inc. v. Walter Cox Co., Inc., 199 N. E. 462 (Ind. App. 1936). See furth $\rightarrow$ Steffen, Independent Contractor and the Good Life (1935) 2 U. of ChI. L. Rev. 501, 518. 
factor ${ }^{6}$ - though it is true he still survived in relatively out of the way places, ${ }^{7}$ and under a different name, as the commission merchant.

It comes with a feeling of surprise-and some vexation-therefore, to find that in the textile field at least, not only has the factor survived all these years, but that he has quite suddenly reached the stage of big business. According to report of James Talcott, Inc., first established in 1854 , it alone "factored" some $\$ 68,162,010$ of business last year. ${ }^{8}$ Moreover, not content with textiles, these new factors are reaching out into different fields for other commodities: rubber goods, electrical appliances, furs, shoes, gloves, fuel oil and what not. The vexation no doubt arises in part from having been so mistaken as to have supposed such a development impossible. And the suggestion of $\mathrm{Mr}$. Achelis, president of one of the largest companies, that the business has been there all the time, waiting, one gathers, only the hand of business genius to be brought forth and entered in the profit ledger-even during a depression-does not help matters much. ${ }^{9}$

But the quarrel goes deeper! One's initial reaction-that is, if one's reactions were conditioned during the long pre-war fight ${ }^{10}$ against the "high cost of living," which seems in outcome to have aided so much in bringing about the very large business enterprise-is, that once again

${ }^{\circ}$ A great many illustrations could be given, the growth of the large milling and baking interests, which substantially occupy the flour trade, being one. The American Woolen Company was a merger of a number of independent mills and now does its own financing and selling. See genera $\rightarrow$ Weld, Marketing Agencies Between Manufacturer and Jobber (1917) 31 QUART. J. ECoN. 571, 576. That writer concludes that "marketing intermediaries are bound to continue in existence indefinitely, especially to serve the smaller manufacturers," but that they are decreasing in importance "in the textile trades where mills are becoming less and less dependent on commission houses for financial support."

${ }^{7}$ This no doubt overstates the matter, for in the produce trade alone-thanks to modern refrigeration-over a million cars of fresh fruits and vegetables were marketed last year, a large portion on a commission basis. NewTon, ConsignMENT MARKETING (1935) 1. A discussion of produce marketing is outside the scope of the present paper.

${ }^{8}$ This figure appears in the company's prospectus submitted to the Securities and Exchange Commission on February 21, 1936. The 1935, volume of "factoring" by subsidiaries of the Commercial Investment Trust (Commercial Factors Corporation, Meinhard, Greef and Co., and William Iselin \& Co.) has been reported at $\$ 245,008,986$ in the official report of the corporation, Feb. 1, 1936-Poor's Daily Reports-Fiscal Companies, at 1836. These, with the Textile Banking Co. (the factoring subsidiary of Commercial Credit Company, which on Feb. 5, 1936 reported a 1935 factoring volume of $\$ 99,118,019-(I d$. at 1818 ) are probably the largest concerns now operating in the field. See generally Sales for Sale (Jan. 1933) 7 FORTUNE 70.

Achelis, The Factor Finds Fresh Fields (April, 1935) 23 Nation's Busrness 32. At page 72 he says: "Evidently many concerns in many industries could always have benefited by factoring. But for more than a hundred years it was taken for granted that factoring was applicable only to the various branches of the textile industry-silk, cotton, wool, and later, rayon."

${ }_{10}$ See for example, Arbuthnot, The Factor System, as Related to Industrial Combinations (1907) 15 J. PoL. Econ. 577. Factoring as here discussed, however, had to do with manufacturer control of dealers, quite a different matter. 
there has been introduced a "middleman," and that, to no discernible economic good. ${ }^{11}$ The complaint is of long standing. In the words of one who wrote so long ago as 1692 concerning the Blackwell Hall factors: "Here are a considerable Party of Men that flourish like Solomon's Lillies, that neither toyle nor spin, that only get a Profit out of the Wool, and no way encourage the Woolen-Manufacture. . ."12 One gathers that the writer was largely concerned with the hard case of the manufacturer in the grip of the factor, a matter of some solicitude even today. But as applied to the position of the consumer today the quotation should perhaps cause even more concern. Why should the textile factor still flourish, and his numbers increase?

It is difficult for a lawyer, moreover, to credit fully the suggestion that business initiative alone is at the bottom of this rebirth. Often the legislature has lent a helping hand. And, however ardently the lawyer may espouse a laissez faire philosophy-at least as respects the hand of the legislator-he cannot have read far without discovering that the courts have themselves built a very substantial legal footing for any business that bids fair to prosper. This the factor and possibly his lawyer are prone to take for granted, as the law of nature so to speak. In other circles it has become commonplace to say that laissez faire is evidently to be abandoned without ever having been tried. ${ }^{13}$ But, however that may be, it is evident that before one can evaluate the position of this "new factor," some investigation must first be made of the legal basis for his business. Possibly also, since we are assured that the common law is the perfection of all reason, we need not inquire further.

The outcry against the textile factor of the 17th century resulted finally in an act of Parliament. ${ }^{14} \mathrm{He}$ was to be regulated! It seems he had been selling on unduly long credit terms, that he had been slow in remitting to the clothier, in fact, that he had used these remittance monies to buy wool to sell to the clothier at a profit. The further charge was made, moreover,- and it is not without counterpart even today - that he used these and other means to ruin the manufacturer, and so to acquire his business. To a society only just changing from a rationing economy, whose main effort was to assure the populace adequate food and clothing, these were serious charges. The act, adopted in 1695 , therefore required the factor to be licensed, limited strictly the credit terms on which sales could be made, provided for periodical re-

${ }^{11}$ See Converse, Elements of Marketing (1931) 14 for a discussion of "the puzzle of high marketing costs."

${ }^{12}$ Clothiers Complaint (1692) 26.

${ }^{13}$ Coker, Property Rights as Obstacles to Progress (1936), Annals, May 1936: "No one, I believe, expects us now to undertake the untried experiment of laissez faire."

${ }^{\text {is }} 8$ \& 9 WM. III, c. 9 (1695). 
ports of sales and goods on hand, insisted upon prompt remittances,and, shortly became a dead letter. Possibly we would say today that it was "unconstitutional," as attempting to hold too close a rein on private initiative. ${ }^{15}$ At all events the factor was able to circumvent it; first by dealings with the poorer merchants, promising them prompt sales and, in the case of sales on credit, by himself guaranteeing the account, for a commission. ${ }^{16}$ But, at least, the unduly acquisitive spirit may have been somewhat chastened.

The factor's next important brush with the authorities, only 50 odd years later, did not involve textiles at all, but logwood brought to England by ship. The forum was different, being that of the Chancery Court, Lord Hardwicke presiding, and "the great Question in the cause was, Supposing Mico [the factor] had a lien on these goods and produce, so as to be entitled to retain them for the balance of the account; whether he has not parted with that right?" The case being in bankruptcy the court was inclined "to equality," but desired the opinion of four merchants in court as witnesses "upon the custom and usage" relating to such matters. Here, obviously, was a sympathetic hearing to learn the needs of business. The merchants were very clear, that, where there was a general account between factor and principal, the factor might retain both ship and cargo not only for particular charges but for any balance due on the general account. But in this case the factor had turned over the goods to his principal's broker and in such event "it is safer for trade" to deny the lien. "It is better to allow that which is the public notorious transaction, than that which is secret." Though Mico lost his case, the factor's general lien, based on possession, had been established, which was no small gain. ${ }^{17}$

It is instructive to note how easily and with what little publicity this bit of law was made. It is only fair to say, of course, that English commerce had expanded greatly in the preceding half century and that a decision denying the factor a general lien-particularly as respects logwood shipped in from out of country-might have caused much greater notoriety. As might be expected Lord Mansfield was quick to approve. Within three years, in 1758 , he wrote: "I take it to be now a settled [sic] point, that a factor to whom a balance is due, has a lien upon all goods of his principal, so long as they remain in his possession." 18 And by 1775 , not only had the textile factor taken over the

\footnotetext{
${ }^{15} \mathrm{~A}$ number of recent cases could be cited.

${ }^{16}$ For an excellent discussion of the whole manoeuvre see Westerfield, MidDLEMEN IN ENGLISH BUSINESS (1915) 296 et seq.

${ }^{17}$ Kruger v. Wilcox, Ambler 252 (Ch. 1755). That this was the turning point case is attested by Lord Mansfield in Green v. Farmer, 4 Burr. 2214, 2218 (1768).

${ }^{18}$ Godin et al v. London Assurance Co., 1 Burr. 489, 494 (1758).
} 
lien for his own uses, but it was extended for him to include "a lien on the price of goods in the hands of the buyer" 19 as well. Though the factor "had not the actual possession" of the goods, "yet as he had a power of giving a discharge, or bringing an action, he had a right to retain the money" 20 paid to him by the buyer, in spite of notice not to do so from the clothier's assignees.

The frank-or at best thinly disguised-partnership between the law courts and the commercial classes at this time evolved a highly dynamic philosophy. In the words of Buller, J., "quick circulation, is the life and soul of trade," 21 and that trade should be promoted, even though at considerable strain to accepted legal doctrine, these judges never doubted. Why was the factor given a general lien? For the very good reason, according to Chambre, J., that his being given one would "encourage factors to advance money upon goods in their possession, or which must come into their hands as factors," a result necessary "for the convenience of trade."22 Nothing could be more explicit. It is not suggested that this conclusion be criticized, but rather that it be lauded, for a whole colonial empire lay at hand awaiting "development." While the lien concept may, as Ames suggests, ${ }^{23}$ have grown up because of the inadequacies of the early action of assumpsit, the factor's version, at least, was to live and have being for the very definite functional purpose of promoting trade.

The actual philosophy behind the first Factors Act, ${ }^{24}$ passed in 1823, is not entirely clear. On the surface at least it was to reverse the case of Paterson $v$. Tash, ${ }^{25}$ which being decided in 1743 , had perhaps not fully appreciated the factor's commercial importance. The court had there held that a factor could not "affect the property" in his principal's goods "by pledging them as a security for his own debt.",26

${ }^{19}$ Drinkwater v. Goodwin, 1 Cowp. 251, 256 (1775). The case is interesting as an out and out financing arrangement with the "factors lien" used as a security device only.

${ }^{20} I d$, at 256. It is interesting to note that nothing was said of the factor holding the receivable as an assignee of a chose in action.

${ }^{21}$ Lickbarrow v. Mason, 6 East 20, 35 (1793). And again: "One great point to be kept uniformly in view is to make the circulation and negociation of property as quick, as easy, and as certain as possible."

${ }^{22}$ Houghton v. Mathews, 3 Bos. \& P. 485, at 488 (1803).

${ }^{23}$ Ames, History of Assumpsit, 3 Select Essays in Anglo-American HisTORY (1909) 259, at 289. Speaking of the tailor's position under the early law in the absence of express contract, Ames says: "having no remedy by action, he was allowed a lien, to prevent intolerable hardship." And, one may guess also, in order to preserve the peace. Even when the action in implied quantum meruit was created, or "discovered" as Ames would have it, it did not displace the innkeeper's old remedy of lien. Watbrooke v. Griffith, Moore, 876 (K. B. 1609). Perhaps tailors and innkeepers, like factors, were to be encouraged.

24 GEO. IV, c. 83 (1823).

${ }^{25} 2$ Strange 1178 (1743).

${ }^{23}$ Ibid. 
Possibly this position would have become untenable in time, though curiously it was reaffirmed in 1794, Grose, J. even saying that in his opinion "it is a wise rule." 27 In 1812 the case of Pickering $v$. Busk ${ }^{28}$ had indicated that the "apparent authority" doctrine might well come to be widely enough expanded to reverse the Paterson case. So, why wait? especially as it was still "necessary to trade" that the factor be encouraged to make advances to his principal. The Factors Act simply closed one eye to the point that money raised on one man's goods might reach quite a different shipper-or reach none at all. The other eye, possibly, was already on the "needs" of the commercial banker.

At all events, it was this English law, in the broad sense, which set the pattern for the growing commerce of the colonists at the close of the 18th century. The factor's lien seems to have been accepted more or less as a matter of course by Kent, C. J. in 1809, when he extended it to cover ship and cargo in the hands of the factors' New York agent on the return voyage. ${ }^{29}$ Previously, in 1804, Judge Bushrod Washington of the newly organized Federal judiciary had even gone so far as to permit a factor, who had waived his lien, to retain the proceeds of certain tobacco shipments and "offset" them on obligations of the shipper planters. ${ }^{30}$ But this is perhaps best understood as Federalist ${ }^{31}$ law. The development did not stop with recognition of the selling factor's lien, however, for in a series of cases beginning with the Massachusetts decision of Stevens v. Robins ${ }^{32}$ in 1815, the buying factor likewise was given not only a specific but a general lien on goods purchased for his principal. The prevailing Federalist politics of the time was not averse to any argument having as its object the promotion of trade.

The factor's lien being thus established, the question to be see-sawed back and forth across the next hundred years had to do with determining the point of time at which it first attached. According to Chambre, J., factors should be encouraged not only to make loans against goods in possession but against those "which must come into their hands as

${ }^{27}$ Daubigny v. Duval, 5 T. R. 604 (1794). There was other strong support for this view. In Queiroz v. Trueman, 3 B. \& C. 342, 351 (1824), Bayley, J. said the rule had "operated much to increase the foreign commerce of this kingdom" by affording a safeguard to the foreign merchant.

${ }^{23} 15$ East 38 (1812).

${ }^{20}$ Urquhart v. M'Ivor, 4 Johns. 103 (N. Y. 1809).

${ }^{30}$ Marks v. Barber, 16 Fed. Cas. No. 9096 (Circ. Ct. Pa. 1804).

${ }^{31}$ See generally, BowERS, JeFFerson AND HAMILTON (1925). For discussion of the early "levelling" laws of the colonies, see Baird, New Deal Laws in Colonial Days (1935) 9 ConN. BAR J. 187.

${ }_{32} 12$ Mass. 180 (1815), a case involving purchase of sole leather. See also Bryce \& Bennie v. Brooks, 26 Wend. 367 (N. Y. 1841). Here the factor had bought rollers for printing calico. 
factors." ${ }_{33}$ The question had political aspects; how far could the commercial factor's lien be pushed forward in the transaction without upsetting notions of fair dealing and law developed in a more static agricultural economy? How elastic was the requirement of possession? In the great case of Haille v. Smith et al.,34 involving a cargo of hemp and iron to London, resort was had once more to eminent merchants for guidance, two this time. In their view it was decisive of the case that the factor had received the bills of lading, for in ocean commerce it was usual in their experience for merchants to accept on faith of such documents. It was ruled accordingly by Eyre, C. J., that the factor took the cargo as against the shipper's bankrupt estate. Actual physical custody was evidently not to be insisted on.

But Haille v. Smith was decided in a sea borne commerce atmosphere. Only six years before, in Kinlock v. Craig, ${ }^{35}$ a case involving a shipment of spirits from Scotland, the factors, or their trustee in bankruptcy, for both shipper and factors had failed before the goods arrived, was denied a lien. "Though the bankrupts might have given their acceptances on the faith that these consignments would be made to them, yet still it was an executory agreement, for the non-performance of which only a right of action accrued," and "no property in the goods was thereby vested in them." 36 No bills of lading figured in the case. And in 1817 , in Nichols $v$. Clent, ${ }^{37}$ a case involving a shipment of flour being sent to Bristol by trow, the factor again lost, although on receipt of the miller's letter of advice he had accepted bills against the consignment. Granted that the factors were correctly dealt with in Kinlock v. Craig, this was a case "a multo fortiori," for "how could the letters give them an equitable right to the goods in the trow." 38 Evidently the factor was not to be greatly encouraged to make advances on domestic transactions, unless he got actual possession; bills of lading were not widely used.

The infant textile industry provided the setting for the first cases on the point in this country. In 1834 a Providence thread maker delivered 10 boxes of cotton thread to a wagoner to take to Boston and leave at the City tavern where he was accustomed to put up. The thread arrived in the evening and was attached by creditors of the shipper, the sheriff storing it temporarily in the harness room. But it appeared that the manufacturer had reached Boston in the morning of

\footnotetext{
${ }^{33}$ See Houghton v. Mathews, 3 Bos. \& P. 485, 488 (1803).

${ }^{34} 1$ Bos. \& P. 563 (1796).

${ }^{35} 3$ T. R. 119 (1789), 3 T. R. 783 (1790).

${ }^{36}$ See 3 T. R. 783, 787 (1790).

${ }^{37} 3$ Price 547 (1817).

${ }^{38}$ See 3 Price 547, 571 (1817).
} 
the same day and procured an advance from the factor with whom he usually traded against an invoice of the shipment. No bill of lading was involved, but the waybill showed simply that the goods were to be left at the tavern. On this state of facts, Shaw, C. J., was clear that nothing had happened to change the "legal possession" of the manufacturer and the factor accordingly lost. ${ }^{39}$ Delivery to the carrier was not delivery to the factor, since delivery was not made pursuant to a previous agreement.

The needs of the textile business were made very much more apparent to the New York court in 1840 and 1841 when Holbrook $v$. Wight $^{40}$ and Grosvenor v. Phillips ${ }^{41}$ were decided by Cowen, J. In the first case, 14 boxes of "sattinets" had been sent by the mill in Middlebury, Vt., to forwarding agents in Troy marked with the factor's name. In the second, brown cloth, manufactured in Auburn, New York, had been delivered to the Auburn \& Syracuse Rail-Road Company for transshipment at Syracuse by canal to New York. In both cases invoices were sent promptly to the factor, describing the goods in detail, but no bill of lading appears to have been used in either case. And while advances made in the Holbrook case appear to have been more or less closely allocated to the shipments, the factor was already in advance to the mill in the Grosvenor case and made no specific advance on the goods in question. What should be done? In the first case the jury came to the factor's rescue with a finding that the shipping agent intended to hold for the consignee, but in the.Grosvenor case it was decided as matter of law, that, in this situation, the factor's claim was superior to that of execution creditors.

How rationalize such a result? Obviously it could not be said to depend upon lien, for here certainly was no actual possession and, at best, but a shadowy constructive possession in the factor. He was, it was argued, but "a mere commission dealer," entitled to no more consideration than any other unsecured creditor. Forced to abandon the "lien" rationale the court resorted to a more potent one,- - the factor had acquired "a vested interest" 42 in the goods. There was precedent, moreover, for Evre, J., had said in Haille v. Smith: "From the moment the goods were set apart for this particular purpose, why should we not hold the property in them to have been changed, it being in perfect conformity to the agreement, and such an execution thereof as the justice of the case requires?" 43 That the factor in the Grosvenor case

\footnotetext{
${ }^{39}$ Baker v. Fuller, 38 Mass. 318 (1838).

${ }^{40} 24$ Wend. 169 (N. Y. 1840).

${ }^{41} 2$ Hill 147 (N. Y. 1841).

${ }^{42}$ Id., at 151 .

${ }^{43}$ See 1 Bos. \& P. 563, at 570 (1796).
} 
had received no bill of lading was a minor matter, for "there is no magic in such a document, especially as between the original parties." 44

At all events here was "law" enough to suit the factor's needs for the time. And, although some courts had trouble in seeing how the factor could have "property,"-inasmuch as the consignor obviously had the "risk" 45 _ still the result was widely approved. ${ }^{46}$ Nor, as might be expected, was it the textile factor alone who benefitted. In 1850, Taney, C. J., speaking for the Supreme Court, was even more explicit in guarding the New York factor's rights to some 350 barrels of mess port which had been attached while in warehouse at Fort Wayne, Indiana, awaiting the opening of transportation in the spring. "To the extent of his advances he is a purchaser, and the legal title was conveyed to him to protect his advances." 47 Why this apparent solicitude for the factor? Because, the transaction represented "the usual course of the great inland commerce by which the larger part of the agriculture productions of the valley of the Mississippi find their way to market" and a decision adverse to the factor "would certainly be not less injurious to the agriculturist and producer than to the merchant and trader." 48 The west, too, needed money.

It is a fair hunch that much the same thought operated also to vest the buying factor with the "property" in goods purchased for his principal; but the record is not so clear. At all events, in the great case of Farmers and Merchants' National Bank v. Logan, ${ }^{49}$ decided in 1878 by the New York court, the result depended on finding "property"-a lien no longer would suffice-in Sears and Daw, the "commission merchants" who had acted for their New York principal in buying a canal boat load of wheat at Buffalo. Although Folger, J., conceded that the principal had the profit and loss risk, still he found with a perfectly straight face that Sears and Daw had the "property."50 It followed,

${ }^{44}$ See 2 Hill 147, 152 (N. Y. 1841).

4s Indeed, the matter of "risk" in the consignor had been mentioned in Haille v. Smith, 1 Bos. \& P. 563 (1796) but the point was not thought of sufficient importance to affect the factor's "property." But in Elliott v. Bradley, $23 \mathrm{Vt} .217$ (1851) it was enough to cause the Vermont court to deny the New York factor any "title" to cloth against which advances had been made. Only four years later, however, in Davis \& Aubin v. Bradley \& Co., 28 Vt. 118 (1855), the case was distinguished by finding a "constructive possession" in the factor, under closely similar circumstances, and so a "lien" for his advances.

${ }^{4}$ But it must be granted the basis was usually by finding a "lien." See generally, Desha, Sheppard \& Co. v. Pope \& Son, 6 Ala. 690 (1844) ; Elliott v. Cox, 48 Ga. 39 (1873); Warren v. First Nat. Bank of Columbus 149 I1l. 9,38 N. E. 122 (1893); Rosenbaum Bros. \& Co. v. Hayes, 5 N. D. 476, 67 N. W. 951 (1896).

${ }^{47}$ Gibson v. Stevens, 8 How. 384, 400 (U.S. 1850).

4 Id., at 399 .

49 N. Y. 568 (1878).

${ }^{50}$ The security nature of this "property" interest on the part of the "buying" factor was set out later more clearly by the court in Drexel v. Pease, 133 N. Y. 
moreover, that the plaintiff bank likewise got the factor's property on taking the bill of lading, for certainly such was the intent of the parties. The next step was a longer one, but it was taken in stride, the "property," moreover, was not lost by giving over the goods into the custody of the principal-buyer on a limited authority. So was born the trustreceipt, which is a different story, but the idea of a split property concept has since become quite orthodox in sales law. ${ }^{51}$

But the Farmers Bank case was also evidence that factoring had two distinct sides: one financing, the other merchandising; and that, moreover, with improved transportation and a developing railroad bill of lading, ${ }^{52}$ the banker was prepared to take an increasing share in the former. Of course, the early case of Haille $v$. Smith, in which the banker had made advances under an arrangement whereby goods would be shipped to his factor-affiliate for sale-and as security-had shown that these functions might easily be separated. Whether it was to meet the banker threat, or because some factors rather fancied themselves in the role of banker, is not clear, but it is well established that by the close of the century a good deal had been happening in the business of the textile factor. Some had come to concern themselves principally with accounts, while others had gravitated to the selling side; thus making two "lillies," so to speak, to grow where but one had grown before.

The famous Ryttenberg $v$. Schefer ${ }^{53}$ litigation marks the transition. While the case did not get beyond Holt, J., in the District Court, it nonetheless spread consternation in the ranks of the financing factors, or their lawyers. Evidently, what was lacking-if anything-in judicial sanction was made up for by the eminence of opposing counsel. The action was brought on behalf of the bankrupt estate of Radon \& Co., Benjamin N. Cardozo of counsel, to recover the proceeds of certain goods and receivables in the hands of the "factor," Shefer, Schram \& Vogel, represented by Charles E. Hughes of counsel. It seems Radon \& Co. had acted as factors for various mills, both selling for and financing them, but had turned over the financing part of this business to Schefer and more recently had been engaging directly in the purchase and sale of goods, again using Schefer as a financing agency.

129, 136, 30 N. E. 732, 734 (1892) : “The correspondent's position is one of ownership so far only as is necessary to secure him for the advances he made upon the merchandise described in the bill of lading, and in such a case as this he is bound to sell upon receipt of the purchase-price from the principal, or in other words, upon receipt of the amount he advanced upon its credit. In no other sense is the correspondent the owner of the property."

${ }_{51}$ Uniform Sales Act $\$ 20(2)$.

${ }^{52}$ In Bailey v. Hudson River R. R. Co., 49 N. Y. 70 (1872) the factor had won, but it was pointed out very clearly that, if the shipper had dicounted his bills of lading with a banker, the latter's rights to the goods would be superior.

sa 131 Fed. 313 (S. D. N. Y. 1904). 
Schefer had taken the precaution, for what it should prove to be worth, to have Radon \& Co. assign over the lease to the premises where the goods were stored and had put up a sign, "Schefer, Schram \& Vogel, Annex," at the entrance. In this situation the court had little trouble as respects the goods for which Radon \& Co. acted as selling agent; these had been consigned directly to Schefer and it was decided that both the goods and the receivables arising from them were subject to the Schefer claim. Of course, so much, at least, was to be expected if the factor's lien-or "property"-meant anything whatever.

The crux of the case had to do with the Schefer position as respects the goods owned by Radon \& Co., and the receivables arising upon their sale. Advances up to $66^{2} / 3$ per cent. had been made on these goods against a statement saying they were "consigned" to Schefer and upon their sale-by Radon \& Co.-up to $75 \%$ on the receivables. In addition, Schefer further guaranteed the solvency of these accounts, intending to assume in this way an obligation similar to that of a del credere factor. Bills to customers went out with Schefer's name at the top, and remittances were customarily made to him. Actually all that had happened was that the financing and the selling functions of the old time factor had been severed, but, in the process, what was to become of the lien-or "property" interest-of the factor? There was no question of the intent and good faith of the parties and obviously the transaction was more or less open and notorious.

It is difficult to recreate at this date the atmosphere in which this case was decided, or to determine exactly what furnished the emotional bent of the court in refusing to accord Schefer a security position, as it did. ${ }^{54}$ The situation was new to the court. One gathers that Holt, J., did not see how Schefer could be called a "factor" at all, since he did not sell. 55 Nor, was the word "consigned" on the statement sufficient to constitute a consignment, for a "man cannot consign a thing to another by merely saying that he consigns it, any more than he can deliver it by mere words." 56 Thus, not content with doubting that Schefer was a factor, the court was further of the opinion that he had not obtained that possession of the goods requisite to a lien. As for the receivables, the ancient Mansfield lien upon the "price"57 went out with the lien

54 The court mentions at the outset that if Schefer's claim were sustained in full there would be no funds available to pay general creditors-or presumably the costs of administration. Id., at 317. There is, of course, no suggestion that this may have influenced the decision.

${ }_{55}$ This attitude is reflected more clearly in the case of Ommen v. Talcott, 188 Fed. 401 (C. C. A. 2d, 1911), which came up very soon after. Here (at 403), Lacombe, J., said, as though the matter were important, "we cannot find out that defendant ever sold a dollar's worth of the bankrupt's goods."

${ }^{5}$ See 131 Fed. 313, 321 (S. D. N. Y. 1904).

st See supra note 19. 
upon the goods and, there being no express assignment, no other basis for a claim upon them was left. Apparently "promotion of trade" was no longer the overweening purpose of the court.

It would have been relatively easy for the court-had it been so minded-to have ruled in the words of Taney, C. J., that the factor had obtained a "title" to the goods. As for the point that the purported "consignment" was no "delivery," it is, of course, a commonplace of sales law that delivery of specific goods is not essential to the buyer's title. ${ }^{58}$ But Holt, J., did not see how this position could be reconciled with the holdings that the consignor has a preferred claim to goods in his factor's hands-over and above the factor's lien interest-upon the factor's insolvency. ${ }^{59}$ Moreover, counsel appear to have been of two minds, for they evidently insisted most strenuously on the inconsistent possessory lien position, relying upon their device of an assigned lease to carry the day. But as to this it was enough for the court to say: "A court of equity looks through the form to the substance."60 Evidently the notion that "equality is equity," which Lord Hardwick had so long ago subordinated in favor of the factor's lien, was once more to have sway.

The case of Ommen $v$. Talcott ${ }^{61}$ which grew out of a similar bankruptcy in 1902 was even more positive in condemning the "assigned lease" as a means of obtaining "possession." And this, in spite of the fact that an employee of Talcott, the alleged factor, had gone through the ceremony of demanding the keys to the premises and then of handing them back again to be held for the lessee. In addition, at the trial, "four" eminent merchants were again produced, according to the best tradition, this time to explain to the court that the word "Annex" after the factor's name at the entrance told all and sundry that the goods stored on the premises belonged to the factor-but for once the court was not impressed. That is, not favorably, for in the view of Holt, J., ${ }^{62}$ this was all merely one more of "the innumerable schemes by which merchants have attempted to create liens on their goods" with "the idea of giving notice enough to satisfy the law and not enough to inform the

${ }^{58}$ Uniform SALES ACt $\$ 19(1)$.

${ }^{\text {s0 }}$ See Baker et al. v. New York National Exchange Bank, 100 N. Y. 31, 2 N. E. 452 (1885).

${ }^{\circ}$ See 131 Fed. 313, 320 (S. D. N. Y. 1904).

${ }^{61} 188$ Fed. 401 (C. C. A. 2d, 1911).

${ }^{\text {ea }}$ One is reminded of the attitude of Lord Holt, some two centuries earlier, when confronted with the argument that bank notes should be deemed taken in absolute, not conditional, payment. "But then I am of opinion, and always was (notwithstanding the noise and cry, that it is the use of Lombard-street, as if the contrary opinion would blow up Lombard-street) that the acceptance of such a note is not actual payment." Ward v. Evans, 2 Ld. Raym. 928, 929 (C. P. 1702). Lord Holt lost out eventually in his important contests with Lombard-Street ; whether rightly or not depends on the viewpoint. 
creditors." ${ }^{3}$ In fact it did not even satisfy the law, nor did the court see any reason to "be astute to discover some equitable lien which the parties did not undertake to create." ${ }_{44}$ It was not until 1920, in Boise v. Talcott, ${ }^{65}$ after various attempts to perfect a common law pledge had failed, ${ }^{66}$ that a cumbersome possession by the factor did satisfy the court.

The Ommen case, however, was useful to the factor on one point; it at least recognized that under some circumstances an "assignment" of accounts receivable would stand up in a bankruptcy proceeding. That is, the court held that, under the contract before it, those accounts where advances had been made upon goods about to be sold should pass to the factor, the assignment being complete when the purchaser received notice by the invoice. There was no consideration of whether an assignment of future book accounts would be valid or not. ${ }^{67}$ And, of course, there was no suggestion that the factor would have a general lien on any assigned account. ${ }^{68}$ Some progress had been made, however, toward repairing the wreckage left by the Ryttenberg case.

Several years were occupied with this litigation, the Ommen case not being finally decided until 1911. Meanwhile, in 1910, the New York legislature had passed a bill ${ }^{69}$ providing simply that liens upon merchandise or the proceeds thereof, when created by agreement for the purpose of securing advances made or to be made, should not be void, provided only the name of the lienor and his designation as factor or otherwise should be posted at the entrance of the place where the merchandise was stored. Here was direct legislative condemnation of the Ryttenberg decision, but the then Governor of New York, Charles E. Hughes, vetoed the bill for the reason that "it would, among the less scrupulous, facilitate secret liens and fraudulent transactions." $\mathrm{He}$ suggested, however, that "Where it may be deemed sound policy to permit a lien by statute in the absence of actual possession, notice of the

See 188 Fed. 401, 404 (C. C. A. 2d, 1911).

idd., at 405 .

${ }^{60} 264$ Fed. 61 (C. C. A. 2d, 1920).

${ }^{6}$ The most spectacular of these attempts came to grief in Security Warehousing Co. v. Hand, 206 U. S. 415 (1907), although it had long before been held, and presumably still is true, that a sufficient possession of a borrower's goods may be obtained-even while they are on his premises-to satisfy common law pledge requirements. Sumner v. Hamlet, 29 Mass. 76 (1831).

${ }^{67}$ For citation and discussion of the early New York cases, see Stone, The "Equitable Mortgage" in New York (1920) 20 Columbia Law Rev. 518, 531, indicating that an unrecorded mortgage of future book accounts is valid and enforceable against creditors. For a Massachusetts holding to the contrary, see Taylor v. Barton Child Co., 228 Mass. 126, 117 N. E. 43 (1917), and see Clanton Bank v. Robinson, 195 Ala. 194, 70 So. 270 (1915).

${ }_{68}$ In fact rather to the contrary!

Assembly Bill No. 2261. 
lien should be required by filing in a public office of suitable and adequate information with respect to the lien and the persons, property and places which it concerns." 70

In 1911, Assemblyman Alfred E. Smith re-introduced the bill. It had been amended to require filing of a notice setting out briefly the name and place of business of the lienor, the name of the person creating the lien, his interest in and the general character of the merchandise and the time for which the agreement was to run. In reference to this provision Mr. Smith said: "The danger to which the Governor referred was, the legislation might facilitate secret loans. That was entirely. removed by the present bill. Nothing could be more public or less secret than the filing of the notice in the office where public records are kept."

Actually nothing could be more simpler than the filing provided for. It was not necessary to describe by marks and numbers any particular merchandise, a broad designation such as "silk," "woolens" or what not being sufficient. There was no requirement that the amount of the lienor's interest should be given. And, when once filed, on payment of a fee of one dollar, ${ }^{71}$ the notice continued effective for the period of the agreement. In the course of the debate on the bill Mr. Hinman (later Mr. Justice Hinman) objected to the lack of any requirement of "specific description," for the bill as drawn would readily permit a shifting of goods to or from the designated premises in fraud of creditors. Mr. Smith answered: "All I can say to the gentleman from Albany is that it ain't possible to make men honest by legislation (laughter). A good many know that if a dishonest man wants to take advantage of our statutes, that we have not many laws on the statute books that you cannot beat." The bill became $\S 45$ of the Personal Property Law.

Thus were repulsed the forces of righteousness led by Holt, J.; you can't make men honest by legislation, not even by judicial legislation, said the voice of the people. And the factor had gained something in the nature of a "floating charge" 72 on a stock of "merchandise

${ }^{70}$ The legislative history of this bill, including Governor Hughes' veto memorandum of June 25,1910 , from which the above is quoted, and the debate quoted hereafter on introduction of the 1911 bill, is available in the brief of the appellant, and in the amicus curiae briefs of the General Motors Acceptance Corporation and Commercial Investment Trust Corporation, submitted in the case of Utica Trust Co. v. Decker, 244 N. Y. 340,155 N. E. 665 (1927).

${ }_{7}$ The filing fees under $\$ 45$, N. Y. Personal Property Law are those provided for chattel mortgages under $\S 234$ of the N. Y. LIEN LAw; twenty-five cents and six cents for a receipt. In NEW YoRk CITY (COUNTY LAw) \&177(2) the fee is one dollar and twenty-five cents for an "instrument affecting chattels" and twenty-five cents for a receipt.

${ }^{72}$ How to provide for a "floating charge" has long given trouble although the desirability of such machinery has been widely recognized. See Stone, supra note 
and the proceeds thereof,"-quite regardless of whether he had possession. This was progress. He could now readily agree that goods are not "consigned," that is delivered, merely because the borrower says they are consigned, for it was no longer of any importance to find a delivery. And it was to be said in respect to Justice Hinman's objection, that the lien as provided by the statute did not necessarily and of itself cover all goods which might happen to be at the posted premises; the practice was for the borrower to "consign" particular goods, that is, to invoice and thus identify the specific goods covered by the lien agreement. So much the factor would insist upon before making advances. But the point was otherwise well taken for, in the exclusive factoring set-up, ${ }^{73}$ the general factoring agreement to which each transaction went back for support was usually drawn as an immediate "consignment" or "pledge" of all goods, evidently of whatever kind or description, which the borrower had or might acquire. ${ }^{74}$ The subsequent invoicing to the factor was thus but further assurance and not essential to the factor's lien, ${ }^{75}$ at least in theory.

Two things of importance had been accomplished, however: first, the word "Annex" was to be translated so that anyone could tell what it meant when posted, without the aid of expert testimony and second, a notice, however brief, must be filed as a public record. What had occurred was a clash between two different ways of doing. For more than a generation the banker's trust receipt security, built on a fiction of title, had been valid without recording of any kind, notwithstanding the goods were given into the hands of the importer. ${ }^{76}$ And, of course,

67 , at 527-529. In some states a mortgage on a shifting stock of goods may be recorded and is valid against creditors, provided the mortgagor does not have complete "dominion" over the proceeds. See Tooze, Oregon Law Relating to Mortgages upon Fluctuating Stocks of Merchandise (1926) 5 ORE. L. REv. 249 (1926) ; Statute Law (1934) 9 Wis. L. Rev. 407. In New York such a mortgage, if not defeated by non-compliance with Lien Law $\$ 230 \mathrm{a}$, the bulk transfer provision, may be valid as to existing stock. Conkling v. Shelley, 28 N. Y. 360 (1863). As to new acquisitions, however, it is not practical since recordation is held invalid against creditors in the case of after acquired chattels. Rochester Distilling Co. v. Rasey, 142 N. Y. 570, 37 N. E. 632 (1894).

.73 It a credit man's commonplace to "sell a factored account on ten days."

${ }^{74} \mathrm{~A}$ typical clause follows: "We shall at all times have exclusive possession and control of merchandise consigned to us as provided herein and as security for our advances and for any and all your indebtedness to us, we shall at all times have a continuing general lien on all of your merchandise, whether the same may be on our premises, at dyer's, processors, finishers, warehouses, in transit or elsewhere." Except for the possibility that the clause "all of your merchandise" might be construed to relate only to consigned goods, this would seem to provide for a general floating charge.

${ }_{75}$ See Irving Trust Co. v. Commercial Factors Corp., 68 F.(2d) 864, 865 (C. C. A. 2d, 1934).

${ }_{76}$ Farmers \& Mechanics Nat. Bank v. Logan, 74 N. Y. 568 (1878); In re James, Inc., $30 \mathrm{~F} .(2 \mathrm{~d}) 555$ (C.C. A. 2d, 1929). See generally, the valuable comparative study of this and other security devices available to creditors, Hanna, Trust Receipts (1931) 19 CALIF. L. REv. 257. 
the consignment arrangement, whereby the consignor retained his interest in goods in the hands of his agent, had always successfully belied possession as an index of ownership-and without recording..77 Always, that is, except as the Factors $\mathrm{Act}^{78}$ had served to protect the particular creditors who had actually relied on the factor's possession. ${ }^{79}$ To a New York merchant, therefore, familiar with these matters ${ }^{80}$ and long accustomed to rely on the financial statement as a credit index, a suggestion that he should estimate a man's actual worth by the goods he had on hand would have been nothing short of preposterous.

So much for banker, merchant and manufacturer,-but the little fellow, unversed in the wiles of the mercantile world, is perhaps still entitled to consideration. Of course, even he may not be so naive as to believe everything he sees; there must be someone to make mistakes so that others may prosper according to their deserts. Laying gross deception to one side-that is "fraud"-which has been frowned upon ever since Twynes case ${ }^{81}$ at least, a moderate amount of sharp dealing has always been part and parcel of a competitive system. ${ }^{82}$ But in the sales field at least the rewards for sharp corner cutting per se have been decreasing - as witness the decline in recent years of that good old doctrine for the promotion of trade, caveat emptor. ${ }^{83}$ No doubt Lord Hardwick had the long range interests of trade in mind when he said it would be better "to allow the public notorious transaction than that which is secret." 84 For, even the larger fellows-or their financial agencies-must be given some means of learning facts; criminal prosecutions $^{85}$ for false statements are often too much like locking the barn after the horse is stolen.

${ }^{77}$ Ludvigh v. American Woolen Co., 231 U. S. 522 (1913). In several southern states, however, provision is made requiring the consignor to post a sign, similar to that required by $\S 45$ of the N. Y. PeRsonal Property Law, in order to preserve his interest as against creditors. See Virginia Traders Act, Va. Code (1930) § 5224 and Edmunds v. Hobbie Piano Co., 97 Va. 588, 34 S. E. 472 (1899). The later cases are collected in StefFen, CaSes on Agency (1933) 561n.

${ }^{78}$ N. Y. Pers. Prop. Law (1915) § 43.

${ }^{79}$ The contrast here is between general unsecured creditors who often will not have relied on the debtor's possession and those relying on the very goods accepted as security. As for buyers, both were reasonably protected, since both trust receipt and consignment arrangements usually, though not always, contemplated sale. Sales in bulk were excluded in so far as affected by the Bulk Sales Act. See N. Y. Per. Prop. Law $\$ 44$ (1935). Under the Uniform Trust Receipts Act, $\S 9$, the purchaser is admirably protected. See HandBook, National Conference of Commissioners on Uniform State Laws and ProceEdings (1933) 263, 264.

${ }_{80}$ Not to mention the various forms of recorded mortgage and conditional sales agreements which make reliance on mere possession almost wholly illusory. See generally Hanna, Extension of Public Recordation (1931) 31 Columbia Law Rev. 616.

813 Co. Rep. 80L (Star Chamber, 1601).

${ }^{82}$ See Radin, The Lawful Pursuit of Gain (1931).

Hamilton, The Ancient Maxim Caveat Emptor (1931) 40 YALE L. J. 1133.

${ }^{84}$ See supra note 17.

${ }^{85}$ Of course such sanctions no doubt have some deterrent value. They are widely used: Criminal Code $\$ 215$, (1909) 18 U. S. C. A. $\$ 338$ (1927) (Using mails 
The compromise hammered out in this fashion by the legislature was a good one. The notice requirements were neither unduly cumbersome-Dean Stone to the contrary notwithstanding ${ }^{86}$ - nor did they fail to give at least a hint of the borrower's actual state of affairs, that is, at least to the larger creditor. It is apparent, moreover, that Taney, C. J., was not so far out of line last century, in finding a "property" interest in the factor who had made advances. ${ }^{87} \mathrm{~A}$ re-reading of the cases so deciding discloses that always the goods were in the hands of a third person-carrier, warehouseman or processor-and never in those of the borrower. ${ }^{88}$ And, in spite of the needless occupation with the question whether "the law" dubbed the bailee agent for the lender or agent for the buyer, the needs of trade usually furnished the answer. Indeed, the unrecorded security title now vested in the holder of a negotiable seller's order bill of lading is justified for no other reason. ${ }^{89}$ It was against this background that Professor Llewellyn drafted the Uniform Trust Receipts Act and shortened the banker's security position, without filing, to a period of 30 days. $^{90}$ So far have the objections of Holt, J., carried.

to promote fraud is a crime) ; Bettman v. United States, 224 Fed. 819 (C. C. A. 6th, 1915), cert. denied, 239 U.S. 642 (1915) (Using the mails to get credit upon a false financial statement is within this section); N. Y. PENAL LAW (1921) §1293b (Misdemeanor to issue a false financial statement).

${ }^{88}$ See Stone, supra note 67, at 533. In England the exception to the general requirement of recordation provided for by the BILL OF SALES ACT (1878) \$ 4 and CoMpanIEs ACT (1929) $\$ 79,2 \mathrm{c}$, that is, of documents arising in the "usual course of trade or calling," takes care of the commercial lender's problem. Under this exception as well as on the usual title rationale the holder of an unrecorded "Letter of Trust" has been held to prevail over the trustee in bankruptcy of the signer. In re David Allester, Ltd. [1922] 2 Ch. 211. So also "letters of lien" given a bank lending on goods at a processors and in preparation for shipment need not be recorded because customary. In re Hamilton Young \& Co. [1905] 2 K. B. 772. The reliance here is therefore purely on the general understanding of the business community as to how such matters are handled.

${ }^{87}$ See supra note 47.

${ }^{88}$ A typical case with an extremely modern ring is that of Nesmith v. The Dyeing, Bleaching and Calendering Co., 1 Curtis 130 (U. S. C. C. A. 1852). It was held that the factor had a security "title" to 500 pieces of cloth in the hands of a processor to be colored as cambric. It is interesting to note the importance attached in the comparable sales situation-specific goods in possession of a third party - to a mere notice to the depository as respects the rights of third persons. See Uniform Sales Act $\$ \$ 34,43(3)$.

${ }^{80}$ UNIForm SAlES ACT $\$ 20(2)$. As to the nature of this "property" interest where the bill of lading is in the hands of a discounting bank, see Note (1926) 26 Columbra Law Rev. 63.

${ }^{80}$ The act as finally approved appears in (1933) HANDBOoK of THE CommisSIONERS ON UNIFORM StATE LAwS (1933) 256. It was adopted in New York, effective July 1,1934 , as $\S \S 50-58 \mathrm{~b}$ of the Personal Property Law. $\varsigma \rightarrow$ Bogert, The Uniform Trust Receipts Act (1935) 3 U. of CH. L. Rev. 26. For several years the act was hung up in committee on the question of whether full recording as demanded by agricultural states, or none at all in accordance with the holdings of the courts of the commercial eastern-seaboard states, should be favored. The compromise finally adopted was a variation of the inexpensive filing under $\S 45$, with but a single central filing (with the Department of State) and no posting required. N. Y. PER. PROP. LAW $\$ 58 \mathrm{e}(3)$. 
But even so the factor was not entirely satisfied with his handiwork, or that of his lawyers; a hole had developed with respect to returned merchandise. Having foreseen this eventuality, particularly where a distressed mill might falsify invoices or ship out inferior goods in order to procure much needed but ill deserved credit, it had long been practice to stipulate in the factoring agreement that such merchandise should be held "in trust" for the factor on its return. ${ }^{91}$ So far so good. But what happened to the factor's interest in the meantime? Obviously he had not retained possession and equally clearly he could not go to the purchaser's place of business and hang up a factor sign to satisfy the statute. When, in 1913, the case first came up in New York the Federal court went back to early concepts-paying no attention to the 1911 statute-and found that as the factor had bought the account receivable he took the returned merchandise. ${ }^{92}$ Just as in Mansfield's day the lien on the goods carried with it a lien on the price, ${ }^{93}$ so here a lien on-or ownership of-the receivable carried an interest in the goods.

But in the case of In re Shulman, ${ }^{94}$ a bankruptcy proceeding coming up in Pennsylvania during the same year, the court took a much different view of the matter. With more assurance than perhaps others would feel in the same situation, ${ }^{95}$ it ruled that the "property" in the goods-raincoats-had passed to the buyer upon shipment. All that the lender had acquired was a pledgee's interest-by assignment-in the receivable. Accordingly when the goods were returned to the bankrupt the effect of the "in trust" provision was either to attempt a new pledge, bad for lack of delivery, or a mortgage, bad for lack of recording, for the title to the raincoats had revested in the shipper. On this reasoning, even had the advance been made upon the security of the goods also, the lien would probably have vanished as the title went to

${ }^{\text {r }}$ A typical provision now in use follows: "If any merchandise, from the sale of which an account is created, shall be returned by or recovered from purchasers, you shall forthwith pay us the amount of such account, either in cash or by the creation of new accounts hereunder, and until such repayment, the merchandise so returned shall be our property."

${ }_{22}$ In re Livingston \& Turk, 205 Fed. 364, 366 (C. C. A. 2d, 1913). "The accounts being no longer available security, it was clearly the intention of the bankrupts to substitute the returned goods. . . Its purpose was not to create a lien but to give the bankers title to the goods. Such an agreement can be and ought to be enforced in equity." But Lacombe, C. J., dissented because at the time when the purported assignment operated "the bankrupts had no title to convey."

${ }^{93}$ See supra note 19.

o* 206 Fed. 129 (E. D. Pa. 1913).

${ }^{25}$ See L. Hand, J. dissenting, in the case of In re Lake's Laundry, Inc. 79 F. (2d) 326,328 (C. C. A. 2 d, 1935), where he says, " "title' is a formal word for a purely conceptual notion; I do not know what it means and I question whether anybody does, except perhaps legal historians." 
the buyer, except as a right of stoppage in transitu $u^{96}$ may have been accorded the lender while the goods were in the carrier's hands. And on return, with revesting of the title in the borrower, the lender would have again been without security. Somewhat legalistic perhaps, but, at all events it was this precedent which Swan, J., chose to follow in the case of In re Bernard and Katz, ${ }^{97}$ which arose in 1930 . To the lenders' argument that he had title to the goods the court said: "We cannot comprehend what such an assertion means."98

While the lender had thus lost $\$ 275$, the proceeds of some 45 dresses, the disquieting feature of the opinion was Judge Swan's blunt announcement, that Section 45 of the Personal Property Law had "nothing to do with the case."99 For, quite obviously, the statement was entirely true. The trouble was that the framers of the 1911 act had had their noses buried so deeply in the Ryttenberg case that they had not bothered to see what was even then happening to the factor's business. Holt, J., had said that the factor's purported lien on goods in his client's hands, and their proceeds, was void, and they had sought, one suspects with some feeling, to have the legislature answer categorically that it was not void. This the legislature did, with qualifications. But the "factor" had meanwhile commenced loaning on receivables to the exclusion of the loan upon goods and by 1930 the factor's merchandise loans had become a relatively small part of his business. ${ }^{100}$ The act, seemingly, had come to have little bearing on the factor's affairs.

In this state of things the case of Goldstein $v$. Rusch ${ }^{101}$ came on for decision. Here the borrower, somewhat more considerate than the borrower in the Bernard and Katz litigation, had told the factor of his impending difficulties on the day before the bankruptcy petition was filed. Without any, unnecessary delay, therefore, the factor sent a truck around and gathered in all "wearing apparel" the bankrupt had on hand which might have been returned merchandise. Of course the factor knew that his action might, as a voidable preference, ${ }^{102}$ be re-

${ }^{2}$ The factor contracts for this privilege and there is no reason apparent why his use of it should not be sanctioned, even though he may now be regarded as merely a statutory factor. See the early case of Snee v. Prescot, 1 Atkins 245 (Ch. 1743).

38 F.(2d) 40 (C. C. A. 2d, 1930).

${ }^{9}$ Id., at 44 .

${ }^{2}$ Ibid. Speaking further of $\S 45$ the court said: "It contemplates the making of a loan on the security of merchandise of which the borrower will retain possession. It does not apply to an assignment of accounts as security."

${ }_{100}$ Achelis, The Expansion of Commercial Factoring, THE BURRoughs ClearING House (July, 1935) 14. "The factor is concerned as a rule only with a manufacturer's accounts receivable, although occasionally he does lend against inventories to tide a manufacturer over a seasonal peak." Prospectus, supra note 8 , at 4 . ${ }_{101} 56$ F. (2d) 10 (C. C. A. 2d, 1932).

${ }^{102}$ At least the master and the court below, Patterson, J., thought so. See the opinion in 54 F.(2d) 86 (S. D. N. Y. 1930). 
garded as not less invalid than undignified. Moreover, under the doctrine of Benedict $v$. Ratner ${ }^{103}$ there was grave danger that, even if his security were otherwise unexceptionable, it might be avoided since the borrower had been allowed a considerable dominion over the goods when returned. ${ }^{104}$ And seemingly the In re Bernard \& Katz decision had denied him either a pledge or a mortgagee interest anyway. But in the opinion of Manton, J., this case was different, the returned goods "in trust" provision in the factoring agreement constituted a pledge, and, the possession being taken before bankruptcy, it related back to the date of the agreement and validated the transaction. The factor had been saved again!

The Goldstein case was decided in the old tradition, that is, for the supposed good of trade rather than for an abstract equality. "Whether enough has been done to give a right of any kind in certain property is a question of more or less," said Holmes, J., in Sexton v. Kessler. ${ }^{105}$ The equitable lien was devised for the very purpose of sustaining the business man's informal security transaction, when entered into in good faith-particularly where no third person's expectations would be disappointed by so doing. ${ }^{106}$ Indeed, this was the accepted means in some states of providing security to the factor for advances against goods still in the hands of the mill. ${ }^{107}$ And so recently as 1922 the Rhode Island court granted the factor an equitable lien on goods in the possession of a receiver. ${ }^{108}$ But at least since the banker's lien on day loans to brokers against securities to be purchased was held invalid, ${ }^{109}$ the remedy has been too uncertain to be useful; it is hard

${ }^{103} 268$ U. S. 353 (1925).

${ }^{104}$ Judge Mack's opinion in Lee v. State Bank and Trust Co. 38 F.(2d) 45 (C. C. A. 2d, 1930) presents the situation nicely where the borrower has such "dominion" as is "fraudulent" as to his creditors.

${ }^{105} 225$ U. S. 90 , at 98 (1912).

${ }^{108}$ As pointed out by Coxe, J. in Livingston v. Turk, 205 Fed. 364,366 (C. C. A. $2 \mathrm{~d}, 1913$ ), goods returned to the bankrupt by a purchaser are in the nature of a windfall to the general creditors.

${ }^{107}$ Garrison v. Vermont Mills, 154 N. C. 1, 69 S. E. 743 (1910) ; James Freeman Brown Co. v. Harris, 88 S. C. 558,70 S. E. 802 (1911).

${ }^{108}$ Contrexville Mfg. Co. v. Oswegatchie Textile Co., 117 At1. 654, 655 (R. I., 1922). "As the Textile Company intended to give security to the Daval Company upon said materials, products, and accounts, the equitable maxim 'Equity regards as done that which ought to be done,' applies."

${ }^{109}$ The legal history of this controversy is ably set forth by Swan, J. in Irving Trust Co. v. Bank of America National Ass'n, 68 F.(2d) 887 (C. C. A. 2d, 1934). The effect of the 1910 amendment to the Bankruptcy Act $\S 47$ a (2) 36 STAт. 840 (1910) 11 U. S. C. A. $\$ 75$ a (2) (1926), is to weaken the position of the holder of an equitable lien, for while the lien may be good against a receiver who "stands in the shoes" of the insolvent company, the trustee in bankruptcy has the position of a judgment creditor. Since $\S 77 \mathrm{~B}$ provides a corporate reorganization on the lines of equity receivership, the cases permitting an equitable lien holder to maintain his security, notes 107, 108 supra, may, however, become useful law even in a bankruptcy court. But $c f$. H. K. Porter v. Boyd, 171 Fed. 305, 313 (C. C. A. 3d, 1919) 
to do business when, to any considerable extent, your rights depend on questions of more or less. ${ }^{110}$

The plot was obviously become too thick for comfort. In 1931, therefore, the legislature again was called upon for assistance and the act of 1911 was amended. The old provision had read that "liens upon merchandise or the proceeds thereof" shall not be void by reason of want of possession, that is, upon filing the notice and posting the sign provided for. But some courts had begun to doubt whether the new factor was really a factor at all, hinting rather openly that he was really a banker, ${ }^{111}$ a wolf in sheep's clothing so to speak. The thought occurred, what if some literal-minded court should next decide, since the lender was not really a factor at all, that the basis for his lien had disappeared? To prevent any such woeful miscarriage of justice, "factor" was therefore defined as any consignee or pledgee who advances money on goods consigned or pledged to him, whether or not he is employed to sell them. ${ }^{112}$ And it was then provided, affirmatively, that such a factor has "a continuing general lien" upon all goods consigned to himwhether or not in his possession-on any accounts receivable or other proceeds resulting from a disposal of the goods. That is, where he has an agreement to such effect.

Surely the factor had now earned a "breathing spell," not that he appears ever to have let his legal pitfalls interfere particularly with his business. At all events, with the insolvency of Nathan \& Cohen, Inc., ${ }^{113}$ a concern operating in the cotton converting business, his legal hopes were largely justified. Swan, J. had no difficulty in holding that goods in the bankrupt's hands were subject to the factor's lien under

which is typical of a contrary line of authority. "In case of a receivership for an insolvent corporation, procured at the instance of general creditors on the ground of insolvency, we are unable to perceive why a secret lien unenforceable at law should not be defeated by the seizure of the property 'by the hand of the court' as effectually as by the making of an attachment or levying an execution by a sheriff."

110 "I desire nothing so much, as that all questions of mercantile law should be fully settled and ascertained; and it is of much more consequence that they should be so, than which way the decision is" per Mansfield, J., in Buller v. Harrison, 2 Cowp. 565, 567 (K. B. 1777). But $\rightarrow$ Frank, Are Judges Human? (1931) 80 U. of PA. L. REv. 17, 33. "The truth is that the talk about the mechanical operation of rules in property, or commercial, or other cases is not at all a description of what really happens in courts in contested cases."

${ }_{111}$ See Shoyer v. Wright-Ginsberg Co., 240 N. Y. 223, 231, 148 N. E. 328, 330 (1925) ; Lemnos Broad Silk Works, Inc. v. Spiegelberg, 127 Misc. 855, 857, 217 N. Y. Supp. 595, 597 (Sup. Ct. N. Y. Co., 1926). For an early doubt in the matter, see Talcott v. Chew, 27 Fed. 273 (C. C. S. D. Ga. 1885).

${ }_{112}$ N. Y. PERs. Prop. LAw $\$ 45$ as amended by L. 1931, c. 766: "The terms 'factor' and 'factors' wherever used in this section include any consignee or consignees, pledgee or pledgees who advance money on goods consigned to and/or pledged with them, whether or not such consignees or pledgees are employed to sell such goods and their successors in interest." 1934).

${ }^{113}$ Irving Trust Co. v. Commercial Factors Corp., 68 F.(2d) 864 (C. C. A. 2d, 
Section 45 , the necessary sign having been posted and notice filed. ${ }^{114}$ Goods at the dyers, as well as finished goods which the factor had consigned to an agent for sale, were both held to be subject to the ancient common law lien, there being no possession in the borrower in such case "giving him a false credit."115 Even the Goldstein v. Rusch"16 case was approved, by way of dicta, for there "the returned goods stood in the place of the validly assigned account, hence no preference. ..."117 It was only the goods purchased after known bankruptcy, and on which no new advance had been made, that were denied to the factor, but that, at least, was a result, more or less to be expected. ${ }^{118}$

Evidently all was at last well with the factor's merchandise lien. But, if the factor thought so, he reckoned without Hubbs, J. in the case of Irving Trust Co. v. Lindner \& Bro. Inc., ${ }^{119}$ decided in April, 1934. The case was simple. It seems the factor had taken actual possession of the merchandise in question, within four months previous to his client's bankruptcy, it is true, but all pursuant to the general factoring agreement. He claimed a lien upon it according to the ancient law. Still, he had not posted the statutory sign nor filed a notice, and, though

${ }^{114}$ In fact the factor here had also assumed such possession of the borrower's goods, by lease, by retention of the keys to the premises and by having employees at work there daily, that the result would have been the same at common law. See Boise v. Talcott, 264 Fed. 61 (C. C. A. 2d, 1920) and compare In re Merz, 37 F. (2d) 1 (C. C. A. 2d, 1930) (where the possession of the factor was not "ostensible" enough and he had failed to file under \$ 45) and In re H. M. Kouri Corp., 66 F. (2d) 241 (C. C. A. 2d, 1933) (despite keys and custodian the lien is statutory and not possessory and may therefore be adjudicated by summary process in the bankruptcy court).

${ }_{115}$ See 68 F. (2d) 864, 866 (C. C. A. 2d, 1934).

${ }^{116} 56$ F. (2d) 10 (C. C. A. 2d, 1932), supra note 101.

${ }^{117}$ See 68 F.(2d) 864,868 (C. C. A. 2d, 1934) ; also compare note 92. This way of stating the thing throws great doubt on the Bernard and Katz decision since it constitutes a return to the theory approved by Learned Hand, J. in the case of In re Worth Lighting and Fixture Co., 292 Fed. 769, 772 (S. D. N. Y. 1923). It was there said: "The return of the goods is a tender by the consignee of goods, instead of money, in payment of his debt."

${ }^{118}$ A transfer of additional security for preexisting advances, after knowledge of insolvency, could at best be justified against the charge of preference as a perfection of an existing equitable lien. But since this property was not in existence at the time of the contract, that is prior to the four months' period, there were no "identified" goods upon which the lien could attach as there were in Sexton v. Kessler, 225 U. S. 90 (1912), supra note 105 and Goldstein v. Rusch 56 F. (2d) 10 (C. C. A. $2 \mathrm{~d}, 1932$ ) supra note 100 . See Burrowes v. Nimocks, 35 F. (2d) 152 (C. C. A. 4 th, 1929), and Britton, Equitable Liens-A Tentative Analysis of the Problem (1930) 8 N. C. L. REv. 388. Of course it might have been argued that it would be "beneficial for trade" to have a factor continue to do business with a client whom he already knows to be insolvent. Lord Mansfield was very clear that the factor should be so encouraged. Foxcroft v. Devonshire, 2 Burr. 931 (K. B. 1760). Such a result might well be achieved, moreover, by giving the factor a lien upon all goods consigned or accounts transferred to him in ordinary course of business before actual bankruptcy, by analogy to the banker's lien-or right of "set-off"-in such case upon the deposit account. New York County Bank v. Massey, 192 U. S. 138 (1904).

${ }^{119} 264$ N. Y. 165,190 N.E. 332 (1934). 
that would have been immaterial under the 1911 provision, ${ }^{120}$ the great question in the cause was whether he should not now be required to do so in view of the 1931 amendment to Section 45 . Here was a very "nice" question indeed, but surely one so only in a Pickwickian sense, for had not the legislature "intended" to relieve the factor rather than to make his life even more burdensome than before. However, how was one to know what the legislature intended?

The court's reasoning was to the point, even if not wholly persuasive. First, it was clear that Lindner \& Bro., Inc. were not really factors, that is "ordinary" factors. They were mere statutory factors or, worse still, mere "commercial bankers." They could have no common-law factors' lien rights-apart from statute-because such rights arise only from "the duty and obligation resting upon the 'ordinary factor' intrusted with the possession of goods and charged with the duty of selling them." 121 Obviously no commercial banker who disdained selling could qualify. As for statutory rights, the case was even clearer, for the 1931 amendment, possibly in an excess of legislative zeal to help the factor, had made the section apply to all goods, "whether in his possession or not." This meant simply that the commercial factoreven when in possession of goods-must file the statutory notice and, presumably, post a sign, ${ }^{122}$ or his lien was void. Such was-or became- the legislative intent.

To a disinterested observer the situation now has its amusing features. Obviously those acting in the factor's behalf over-reached themselves by the 1931 amendment. Nor was it ever very clear how they expected it to cure the returned goods difficulty presented by In re Bernard and $\mathrm{Katz}^{123}$-unless the provision for a "continuing general lien" was to make the factor's interest survive. ${ }^{124}$ But, on the other hand, Hubbs, J. seems to have fallen into a logical error in deciding that because the new factor is not like the old-in that he does no selling-it follows that he has no lien. ${ }^{125}$ And the "cogent" reason

${ }^{120}$ See 264 N. Y. at 172,190 N. E., at 335.

${ }^{121}$ See 264 N. Y. at 174,190 N. E., at 336.

${ }_{122}$ This would evidently require posting at the factor's own place of business, since the sign must be posted where the goods are stored.

${ }^{123} 38$ F.(2d) 40 (C. C. A. 2d, 1930), supra note 97.

${ }^{124}$ What the word "continuing" was intended to mean is not clear. It may have been intended to assure a prospective action to the lien as in the case of a continuing guaranty. See Henry McShane Co. v. Padian, 142 N. Y. 207,36 N. E. 880 (1894). Or, more likely, to assure the continuance of the security as the goods are moved from point to point. See McFarland v. Wheeler, 26 Wend. 467 (N. Y. 1841).

${ }^{125}$ Compare the similar reasoning of the court with respect to a variation from the "regular" C.I.F. contract. Cundill v. A. W. Millhauser Corporation, 257 N. Y. 416,178 N. E. 680 (1931). 
found in the legislative mind, ${ }^{126}$ that the amendment was to prevent evasion of the bankruptcy act as approved in Goldstein v. Rusch ${ }^{127}$ on the doctrine of relation back, would be hard to support by reference to legislative records. Rather, the robust common sense of Swan, J. in sanctioning a possessory lien-regardless of how the new factor should be classified-so long as no "false credit" had been given the borrower, ${ }^{128}$ commends itself as sound. For surely the legislature had no intention of upsetting the age old possessory lien, merely to legislate concerning the relatively infrequent case where the relation back doctrine has application-even if the court's interpretation did permit it to correct a curious inconsistency in its own holdings. ${ }^{129}$

At all events "the people" were not pleased with the court's interpretation, for in 1935 the section was again amended. It now provides specifically that a factor has a "continuing general lien"-where he has contracted for it-upon any goods in his possession or in the possession of "any third party" for his "account," all without filing or posting. ${ }^{130}$ That the common law possessory lien is valid should now at least be clear. But whether the court will retreat from its position condemning the "relation back" doctrine is not at all clear. The legislature said something further to the effect that the section should not be construed as affecting "any rights at common law" but what that means, no one knows. ${ }^{131}$ In 1931 it had said that the section should be construed "liberally" to secure "the beneficial interests and purposes thereof." But what is "beneficial" is a matter of some doubt.

So ends this chronicle of the factor's adventures before the courtsand the legislatures. Though at times discouraged still, withal, he has had his successes. What of the future? It will be assumed that this depends on who the new factor really is, or rather, on what contribution he can be said to make to the economic life of the time. If one thing more than any other is clear up to this point, it is that the courts through the years have given him powerful support in the attainment of

. ${ }^{126} 264$ N. Y. 165, 190 N. E. 332 (1934), supra note 119.

${ }^{127} 56$ F.(2d) 10 (C. C. A. 2d, 1932), supra note 101.

${ }^{128}$ See Irving Trust Co. v. Commercial Factors Corp., 68 F.(2d) 864, 866 (C. C. A. 2d, 1934), supra note 113.

${ }_{120}$ The inconsistency is between the holdings with respect to chattel mortgages and pledges. In the case of the former, possession taken within four months of after acquired goods does not relate back to the original contract as a perfection of a prior existing equitable lien. See the Zartman v. First National Bank, 189 N. Y. 267,82 N.E. 127 (1907) line of authority. In the pledge case "relation back" is permitted. Parshall v. Eggert, 54 N. Y. 18 (1873) and see Sexton v. Kessler, 225 U. S. 90 (1912), supra note 105.

${ }^{130}$ Laws 1935 , c. 690.

${ }^{131}$ The implication is possible that the legislature meant to reëstablish the right to perfect the lien of an equitable pledgee by possession taken even during the critical 4 month period, which had been established without its assistance See supra note 129. 
his purposes. But it is equally clear that in the last quarter century there has been doubt; the old confident singleness of purpose, the further "promotion of trade," has been lacking at times. Or possibly the doubt has been whether the present factor contributes substantially to that end. Though he appears to show a profit, there has been a feeling that profit, like virtue, is its own reward-and that the courts need no longer be unduly solicitous of his affairs.

It is not possible in the remaining pages even to attempt to whitewash the new factor's economic life; besides, if that is desirable, it can be much better done by an economist. ${ }^{132}$ It is evident, however, that he has been retiring to an ever safer position; no longer is he at the outposts selling the nation's goods. Where once the textile factor had a little office in the corner of a warehouse stacked with merchandise he now occupies whole floors with no goods in sight. ${ }^{133}$ But even in the beginning selling was not the factor's sole, or necessarily his most important, function. The lien was given according to Chambre, J. "to encourage factors to advance money," 134 not primarily to sell goods. Or, one might say equally, to encourage the factor to guarantee the purchaser's account, for the del credere factor seems always to have had a lien on goods and the resulting receivable. ${ }^{135}$ Both these services the modern "factor" performs. In addition, for his own protection and incidentally for that of his client, he supplies a highly skilled credit service. $^{136}$ And, encouraged therein by Benedict $v$. Ratner, he has further kept a close hand on collections, another important service to his client. ${ }^{137}$

Whether a concern doing such things is properly called a factor is of course now beside the point. It is evident that as his interest has come to center in the receivable-rather than in the merchandise-his service approaches more closely that of the banker's. But when it has been suggested, once or twice, that he is in fact a banker-and should be regulated ${ }^{138}$ or taxed ${ }^{139}$ as such-there has been serious objection.

${ }^{132}$ Compare Seligman; The Economics of Installment Selining (1927).

${ }^{133}$ See supra note 100.

${ }^{134}$ Supra note 22. REv. 221.

${ }^{135}$ See supra note 19 and see R. S. T. Chorley, Del Credere (1929) 45 L. Q.

${ }^{138}$ One of the factor's chief "selling points" in getting new clients is that for a small commission he assumes all the burdens of credits and collections.

${ }^{137}$ See supra note 103 . Because the accounts are payable directly to the factor there can be no question of allowing his client too much "dominion" over the proceeds.

${ }^{138}$ That is, comply with banking law. See In re Worth Lighting \& Fixture Co., 292 Fed. 769, 773 (S. D. N. Y. 1923), supra note 117, where Hand, J. said of the factor that he "is doing a business precisely like a pawnbroker, except that the pawns are not chattels." At all events, that the factor was not "discounting bills, notes or other evidences of debt" as a bank was thought to be clear.

${ }^{130}$ People ex rel. James Talcott, Inc. v. Goldfogle, 242 N. Y. 544,152 N.E. $420(1926)$. 
For this purpose, at least, the "factor does something more than merely loan money."140 And, conversely, it has been pointed out that banks never make advances on goods or the receivables resulting from their sale and that they do not guarantee accounts nor do they have any facilities for storing goods. ${ }^{141}$ Of course to anyone acquainted with present day banking this is essentially incorrect, as is the suggestion that the modern factor is primarily concerned with goods.

But it is true that the banker way of doing these things is different. $\mathrm{He}$ has different machinery and, it may be said, a different psychology. ${ }^{142} \mathrm{He}$ does not advertise Sales for Sale, ${ }^{143}$ but on the contrary, the lowly borrower must approach him hat in hand, that is until recently. But he positively does make loans against goods, whether in storage or transit, if they are represented by a negotiable document. $\mathrm{He}$ positively buys or makes advances on receivables ${ }^{144}$ _but they must be in negotiable form. Indeed, in many cases now, he makes advances against the same type of receivables as does the factor. And, while his efforts to guarantee accounts long were obstructed by the ultra vires doctrine, ${ }^{145}$ he now does the same thing by issuing a letter of credit undertaking himself to accept and pay the seller's draft. The circumstance that it is the buyer in the letter of credit transaction who arranges for the credit, while it is the seller who initiates things in the factor set-up, would seem to be of no especial functional significance. ${ }^{146}$ It is the sale that is being financed in either event. These and other differences in form, however, may save the factor from regulation yet awhile as a banker. ${ }^{147}$ On the other hand, the underlying similarity in function should possibly entitle the factor to a share in the favor which the banker has enjoyed through the years.

Possibly it is the finance company, the factor's neighbor on the left, which has caused the courts at times to look askance at the factor. In terms of fees, however, the line between the two is very marked.

${ }^{140}$ Dowling, $J$. in the opinion in the same case in the Appellate Division, 213 App. Div. 719, at $725 ; 211$ N. Y. Supp. 122, at 128 (1st Dept. 1925).

${ }^{141}$ See the testimony of Herbert P. Howell, then an officer of Peierls, Buhler $\& C_{o}$., as summarized in the case, 213 App. Div. at 724, 211 N. Y. Supp. at 127.

${ }_{142}$ See Robinson, Law and Lawyers (1935).

${ }^{14}$ Sales for Sale (Jan. 1933) 7 FORTUNE 70.

${ }^{144}$ For a discount case taking the lien view, see Barton Seed, Feed \& Implement Co. v. Mercantile Bank, 128 Tenn. 320, 160 S. W. 848 (1913).

${ }^{145}$ See Pan American Bank \& Trust Co. v. National City Bank, 6 F.(2d) 762 (C. C. A. 2d, 1925) where the statutory basis is considered.

${ }^{149}$ Indeed, as the Uniform Trust Receipts Act is drawn it is entirely possible, though somewhat foreign to his habit of thought, for the factor to use the trust receipt device in releasing goods to the buyer.

${ }^{147}$ Nor is his business quite that of an insurance company, though his "purchase" or "guaranty" of accounts has some resemblance to credit insurance. 
The cost of money borrowed from the wholesale 148 "finance" or "discount" company averages from 15 to $20 \%{ }^{149}$ The factor on the other hand charges a fee of about $2 \%$ and interest at the rate of $6 \%$ for advances actually made. ${ }^{150}$ The difference is due to differences in the way the two businesses are run. In the first place much of the finance company business is done on a non-notification ${ }^{151}$ basis, forced in part by the adverse business and banking attitude toward anyone who has to "hock his accounts." 152 The result is that, not only may a company not infrequently have to contest its title to the account, ${ }^{153}$ but it is forever being faced with loss due to the Benedict $v$. Ratner situation. ${ }^{\mathbf{1 5 4}}$ But probably the real, though less tangible difference, lies in the fact that the factor has grown up out of a merchandise background-he still knows something first hand of styling, of budgeting production, of credit conditions and such matters-while the finance company, and to a lesser extent the banker, ${ }^{\mathbf{1 5 5}}$ has been concerned almost exclusively with the receivable.

${ }^{148}$ The finance company here referred to does its business by lending money on the security of the book accounts of manufacturers and wholesalers. It should be distinguished from the finance company (frequently the same one) doing a business in purchasing retail conditional sales contracts from dealers in automobiles. radios, refrigerators, furniture and the like. See Adelson, The Mechanics of the Instalment Credit Sale (1935) 2 Law and Contemporary Problems, 218.

${ }^{149}$ Chapin, Credit and Collection Principles and PRACTICE (1929) 287. Besides these charges the borrower still has bad-debt and collection costs to meet.

${ }^{150} I d$., at 292 , says the average charge is about $11 / 2$ to $2 \%$. Variations in the size of receivables and the type of purchasers sold, lower interest rates on money borrowed by the factor from the banks and competition for clients leads to variations in this average. For a practical insight into the mechanics of the factor's business, the lectures on factoring given by I. Edwin Goldwasser, President of Bachmann, Emmerich \& Co., at New York University School of Commerce (unpublished) have proved invaluable.

${ }^{151}$ The debtor is not notified of the assignment but pays his bill directly to the borrower-assignor. See, Laucheimer, Some Problems of Modern Collateral Banking (1926) 26 Columbia Law Rev. 129.

${ }_{152}$ Due to its high cost, see supra note 149 , this form of financing is only resorted to when all other doors are closed to the borrower. That being so, whether cause or effect, it usually means the borrower's credit is exhausted. Factoring, being a regular course of business, is not such a danger signal. But compare Manton, J., in Boise v. Talcott, 264 Fed. 61 (C. C. A. 2d, 1920), supra note 65. "This method of financing an embarrassed commercial concern in this line is common, and the right to do so is recognized by the courts." (at p. 64.)

${ }^{153}$ See for example, Salem Trust Co. v. Manufacturers' Finance Co., 264 U. S. $182(1924)$.

${ }_{154}$ Typical are: Lee v. State Bank and Trust Co., 54 F. (2d) 518 (C. C. A. 2d, 1931) ; Manufacturers' Finance Co. v. Armstrong, 78 F.(2d) 289 (C. C. A. 4th, 1935 ); In re Lambert and Braceland Co., 29 F.(2d) 758 (E. D. Pa. 1928). "The outstanding result of these several legal restrictions upon the assignment of book accounts as collateral security is to penalize heavily the business forced to resort to the practice." See Note (1935) 44 YALE L. J. 639, 649 containing an encyclopaedic treatment of the legal problems involved in "non-notification" finance company practice. And see Glenn, Book Accounts as Collateral (1926) 26 Columbia LAW REv. 809.

${ }^{155}$ CHAPIN, op. cit. supra note 149 , at 290 , points out that owing to his more intimate connection with the business, "Much larger sums are advanced by the factor 
Then too the factor says he "buys" the account instead of merely loaning against it as security. ${ }^{156}$ But so too does the banker when he discounts a draft ${ }^{157}$ and the assignment of accounts to a finance company at least reads like a present sale. ${ }^{158}$ The measure of truth in the factor's statement, however, lies in the extent to which recourse is reserved against his client. The banker takes an indorsement, the finance company an express contract-thus putting the ultimate financial risk in each case upon the client ${ }^{159}$ - but the factor agrees to take this risk himself. ${ }^{160}$ A very broad difference indeed! What has happened is that "the del credere contract" of the factor-spelled out slowly and at great pain and cost by the courts-has been carefully reworded. ${ }^{161}$ The ancient argument whether it constitutes a guaranty of payment or of collection ${ }^{162}$ is gone; the factor undertakes to advance the full price of the receivable at maturity, whether the receivable is paid or not, and conversely may "charge back" the entire account at any time prior

to the factored mill than a bank would be willing to advance on an unsecured basis, and the form of security which the mill can offer is not the kind of security that the commercial bank would be willing to accept." This is, of course, more true of the merchandise advance than of the accounts.

${ }_{158}$ The subtitle to Achelis' article cited supra note 100 is: "The purchasing of accounts receivable is not a new practice but a practice that has been spreading to new lines of business."

${ }^{157}$ See, for example, Weed v. Boston \& Maine R. R. 124 Me. 336, 128 Atl. 696 (1925) and for a discussion of the matter, Turner, Deposits of Demand Paper as "Purchases" (1928) 37 YALE L. J. 874.

${ }^{15 s}$ See Le Sueur v. Manufacturers' Finance Co., 285 Fed. 490 (C. C. A. 6th, 1922) cert. denied 261 U. S. 621 (1922). But cf. In re Eby, 39 F.(2d) 76 (E. D. N. C. 1929).

${ }_{\text {iso }}$ See Le Sueur v. Manufacturers' Finance Co., 285 Fed. 490 (C. C. A. 6th, $1922)$ at 496. Compare recourse and non-recourse "purchasing" of retail conditional sales contracts as set forth in Cavers, The Consumer's Stake in the Finance Company Code Controversy (1935) 2 Law and Contemporary Problems 200. Where the factor purchases trade acceptances instead of book accounts, a new contract in use in the fur trade provides: "All commercial paper so purchased by us shall be bought by us without recourse to you on said commercial paper as such, and shall be endorsed by you without recourse. . .."

${ }_{100}$ Because he agrees to take the financial risk of the purchaser's solvency, control exercised by the credit department of an integrated business must be allocated to the factor. So stipulations permitting such control must be included in the sales contract of his client out of which the account arises. See generally: Siegel v. Huebshman, 187 App. Div. 548, 176 N. Y. Supp. 71 (1st Dept. 1919) ; Peierls, Buhler \& Co., Inc. v. Newburger, 202 App. Div. 471, 195 N. Y. Supp. 142 (1st Dept. 1922) ; Havighurst, Clauses in Sales Contracts Protecting the Seller Against Impairment of the Buyer's Credit (1936) 20 MinN. L. Rev. 367.

${ }_{101}^{1}$ In Newburger-Morris Co. v. Talcott, 219 N. Y. 505, 511, 114 N. E. 846, 847 (1916), Cardozo, J. had said that a del credere factor must first reimburse himself out of goods in his hands for sale. The holding in Shoyer v. Edmund Wright-Ginsberg Co., 240 N. Y. 223, 148 N. E. 328 (1925) is that such is not the case where the factor is a "commercial banker" type of factor rather than a sales agent. See 240 N. Y. at 233, 148 N. E. at 331.

${ }_{162}$ See Lewis, Brothers \& Co. v. Brehme, 33 Md. 412 (1870). 
thereto in event of a merchandise dispute. ${ }^{163}$ Only the banker in the commercial credit transaction assumes a greater obligation to the seller, since the agreement there is to pay against documents whether the goods conform or not. ${ }^{\mathbf{1 6 4}}$

More than all else, it would seem, the factor owes his existence today to the stubborn persistence of the open book account way of doing business. The banker's trade acceptance, though widely publicizedand even, by rediscount by the Federal Reserve Banks, made directly convertible into money-does not afford the buyer an opportunity to assert defenses, or sufficient leeway to "jockey" and "chisel." So a fortiori with the banker's letter of credit machinery. But with equal certainty here were assets of enormous value which, to use the words of Buller, J., in speaking of goods covered by an ocean bill of lading, could not remain "locked up" forever. ${ }^{165}$ Being highly liquid there was a place for them in the market. An economical use of capital demanded that they be brought to market. If a large strata of business would not conform to the banker way of life, the obvious thing to do was to shape financial machinery to fit the business view. The amazing thing is not that the factor is now doing this but that the development has been so long delayed, and painful.

Taking a larger view of the matter this transition in the factor's business is but an eddy in the broad movement, at least two centuries old, ${ }^{\mathbf{1 6 6}}$ looking toward an ever increasing liquidity. ${ }^{\mathbf{1 6 7}} \mathrm{A}$ vast increase in incorporation, negotiability accorded to the share certificate and to the various commodity documents, the greater standardization of goods, all developments of the last quarter century, have greatly accelerated the movement. As to why we are mobilizing an ever increasing amount

${ }^{163}$ In part to cover the contingency of "charge-backs" impairing his security the factoring contract usually provides for advances only up to a percentage of the total receivables purchased. Goldwasser, supra note 150, argues for a "reasonable amount" rather than a fixed percentage of reserves as being more flexible. See e.g. Shapiro Bros. Factors Corp. v. Cherokee Silk Mills, 176 Atl. 893 (N. J. L. 1935) where $85 \%$ was allowed. In Irving Trust Co. v. B. Lindner \& Bro., 264 N. Y. 165,190 N. E. 332 (1934), supra note 119, a lien on the accounts was permitted even after they had been "charged back," where the contract so stipulated. This is consistent with the result reached in the banking "charge-back" cases. Royal Bank of Scotland v. Tottenham [1894] 2 Q. B. 715; Union Electric Steel Co. v. Imperial Bank, 286 Fed. 857 (C. C. A. 3d, 1923).

${ }^{104}$ Maurice O’Meara Co. v. National Park Bank, 239 N. Y. 386, 146 N. E. 636 (1925).

${ }^{165}$ See supra note 21.

${ }_{168}$ The Bank of England was organized in 1692, which may fairly be said to have been the start of modern banking. Powenl, Evolution of THE MoNEY MARKET (1915) 58, 62.

${ }^{167}$ See also Steffen and Russell, Registered Bonds and Negotiability (1930) 47 Harv. L. Rev. 741. The time may have come for the Commissioners on Uniform State Laws to explore the possibilities of drafting uniform factoring legislation. 
of property in liquid form has not been determined, or particularly questioned. At the same time, that "an economic structure based on liquidity must almost of necessity be fragile," to quote from Berle's brilliant essay on the subject, ${ }^{168}$ cannot well be gainsaid, any more than that the device can "prove useful." Whether the new development in the factor's business is socially desirable or not is thus too broad a question to answer; but that he builds in a long tradition is evident enough.

Roscoe T. Steffen

FREDERICK S. DANZIGER

YaLe University School of Law

13.

${ }^{1 e s}$ Berle and Pederson, Liquid Claims and National Wealth (1934) 12, 